\title{
Economy development of the Russian Federation regions at the present stage
}

\author{
Timergaziz Sadykov*
}

Ufa State Petroleum Technological University, Branch of the University in the City of Oktyabrsky, 54a, Devonskaya St., Oktyabrsky, Republic of Bashkortostan, 452607, Russia

\begin{abstract}
At the present stage of market relations development for the scientific substantiation of economic reforms, the regional economy is of particular importance. The region today is becoming the main object of economic and political relations, and in this situation, it is very important to determine the specifics and priorities of the formation and development of the regional economy. The purpose of this article is to study the influence of interconnection, interaction of all elements of the regional economy and competent management of them for the purpose of effective development.
\end{abstract}

\section{Introduction}

The traditional approach to the "region" as part of the country, often combined with the peculiarities of the population national composition, as well as major economic growth, a federation subject, including the republics, territories, regions, autonomous region, autonomous area with the population of public and administrative authorities.

The economy of region is a science that studies and organizes economic processes in each individual region and, as a result of the data obtained, determines the further development of the region by developing a specific program.

The regional economy depends on the political situation in the country, and the political situation of the state as a whole, on the economic situation of each individual region.

\section{Results and discussion}

\subsection{The current state of the economy}

The current state of the economy of the Russian Federation regions can be defined as stable with minor positive changes after a decade-long recession. In recent years, as a consequence of the growth in world oil prices, the crisis state, as well as, the economy of Russia and its regions received a unique chance, which led to a reduction in imports and an increase in the production and consumption of domestic goods and services [5].

Currently, as a result of the adoption of new economic relations in the country, the regional economy faces serious challenges in developing a new management mechanism and the social and economic development of each region.

The regional economy should ensure a high quality of population lives. At the same time, taking into account the needs of the population, it is necessary to take into account the interests of the state and enterprises in the region. A necessary element is also adaptability to external and internal factors.

In most works of economists (until 2000) devoted to the regional economy, the position of the center in the economic, social, national, demographic and other spheres is reflected. Their main drawback is the underreporting of regional factors and characteristics. In this article would like to show the economy of the region from its internal position [15].

\subsection{Regional Economic Policy}

The main goal of the regional economic policy is this general goal in the management of any economic system: economic growth by increasing efficiency and using the resources available to the region (natural, labor, capital and financial) [2].

Of course, the main task of the regional economic policy is to strengthen the economic basis of the regions and preserve the territorial integrity and stability of the state as a whole.

The Russian Federation is a unique state. Uniqueness is that it consists of a variety of subjects. With the same status as subjects, there are deep differences between them in terms of geographical location and natural resources, historical and socio-economic development, and others.

Differences in relations with the federal center in relation to property, land, financial and credit and tax spheres also persist; there are features in the approaches to the militaryindustrial complex.

It is obviously wrong to equate them to each other.

The fundamental cause of economic inequality is the concentration of economic activity in territories that have a competitive advantage, that is, the provision of natural 
resources, favorable geographical position, level of human capital [3].

The development of the economy of regions in 20192020 will certainly continue, although not at a high rate. According to forecasts of the financial university under the Government, the greatest economic growth in 2019 can be expected in the Republic of Crimea and in Sevastopol. The Amur Region, the Chechen Republic, the Samara Region, the Republic of Sakha (Yakutia) are also among the leaders in terms of the growth of the GRP [1].

It should be noted what to expect in 2019-2020 a sharp rise in the economy of regions is not worth it. According to experts in 2019, the state will begin to orient the population to the next crisis turn. This is due to the fact that the resources of the reserve fund have been exhausted and by 2020 the national welfare fund. Consequently, the government will look for options to replenish the budget. The main directions in this will be:

- a new wave of privatization;

- tax increase;

- reduction of social expenditures.

To save the economies of the regions and the whole country, it is necessary to focus on small and medium businesses.

Positive forecasts of the oil market of the regions are determined by ensuring a substantial increase in the revenue part of the budget in 2019. As a result, analysts predict an increase in key indicators:

- GDP increase at $1.5 \%$ in 2019 ;

- acceleration of economic growth in 2019 by $2.9 \%$;

- GDP will add 1.0-1.5\%.

The forecast also preserves the cost of oil at $\$ 65-70$ per barrel. At the same time, the demand for "black gold" will increase, which is associated with the revival of the global economy [14].

Experts believe that a further increase in geopolitical tensions may lead to the isolation of the domestic (regional) economy.

Unlike foreign analysts, the forecast for the growth of the country's economy (regions) for 2019-2020 is no more than $0.3-0.4 \%$. In general, most economists predict a slow rise in the Russian economy.

But, given the unstable foreign policy situation around the state, it can be assumed that the indicators can change drastically [13].

\subsection{Economics of Transition. (On the example of the Republic of Bashkortostan)}

An analysis of the works of many learned economists has shown that any transition from one economic state to another is accompanied by painful phenomena. The transition to a market economy is no exception. While Western countries gradually shifted to market relations over the centuries, obeying the objective laws of social development, the Russian Federation had to make market transformations while simultaneously eliminating the principles of command and control management in the economy [2].

Consider these problems on the example of the Republic of Bashkortostan. Thanks to the rich natural resources, with the support and assistance of the center and other republics during the years of Soviet power, the republic has accumulated powerful potential. It expressed himself in the rapid development of agriculture and other industries. In different decades, the Republic took over a significant part of the union programs in energy and chemistry. Sometimes at the cost of breaking the vital conditions for the population of the republic itself.

With each passing year, the lack of an information base adequate to the economic potential began to be felt more and more. This situation has gradually become a factor hindering the development of the republic's economy. This led to the fact that by the 1990s $97 \%$ of the property (enterprises, mines, factories) in the territory of the republic belonged to the union, republican ministries and departments. The share of deductions from these enterprises to the regional budget was not weighty, and its budget, according to the constitution of the republic, was dependent on the all-Russian $[14,15]$.

In the 1990s, Bashkortostan, together with other regions of the country, supported the development of economic independence as a region. As a result, the Republic acquired a special budget status, which from 1991 to 1993 practically did not transfer taxes to the federal budget. This gave a huge impetus to the development of the republic's economy.

Republic in the transition period to the market has undergone fundamental changes. The transition from the prevalence of state ownership to a variety of forms of ownership and management; the orientation of enterprises has changed radically in favor of the republic's jurisdiction; structural changes occur in the economy.

Currently, in terms of economic activity and sectors in the national economy, the republic is one of the leading regions of Russia. The economy of Bashkortostan has a diversified structure. The branches of industry specialization are fuel and energy complex (FEC), oil refining, chemical and petrochemical industries, engineering, forest industry, etc.

It should be noted that in terms of oil production, the republic is in 9th place in the Russian Federation, in its processing and production of petroleum products [15].

\subsection{Development strategy}

The regional economic development strategy is activities aimed at the implementation of long-term projects, taking into account the contribution of the regions to their solution.

It may vary depending on the socio-economic and political direction of the region at a specific stage of development [7].

In recent years, in connection with the increase in independence, the regions themselves are responsible for the results of economic development.

The development of the economy of region today is not so much quantitative growth, but rather qualitative changes, i.e. the activity essence of the region.

If you pay attention to the availability of resources, the main factor is not the availability of resources. And the effectiveness of their use.

Due to the complexity of the socio-economic processes that are the subject of the regional economy, we can identify the main problems at the present stage [6]: 
- the economy of a separate region;

- economic ties between regions;

- regional systems (national economy as a system of interaction between regions);

- regional aspects of economic life.

Summarizing the many programs and strategies adopted by the Russian government on economic development for the period up to 2025 , one can say that the growth rate in the next seven years will not be surprisingly high, but the situation will gradually improve.

In the next three years, it will be $3.3 \%$ and exceed the world average, and in 2021-2025 the growth rates will be outpacing almost 5\% per year.

The Presidential Council on Strategic Development and Priority Projects reviewed the Digital Economy program. At the suggestion of the President, at least ten high-tech and competitive enterprises in global markets, ten "industrial digital platforms for the division of economic activity" will appear in Russia in 2024. By this time, 500 small and medium enterprises "in the field of creating digital technologies" should work successfully in the country, universities will produce 120 thousand IT specialists a year, at least 30 research projects in the digital economy should be implemented with a budget, not less than 100 million rubles and etc.

The main ideas of the "Principles of the Strategy of Economic Development of Russia until 2025" presented to the public require revision. In this regard, a number of events were organized, involving discussion of the abovementioned document with entrepreneurs and representatives of regional chambers.

Discussion of the document by a number of member organizations of the Chamber of Commerce and Industry of the Russian Federation, the expert and scientific community at both the federal and regional levels will allow for a deeper analysis of the characteristics of the country's socioeconomic development, its regions, and the implementation of industrial policy. The package of measures under this document is aimed at leveling the competitive conditions of domestic and foreign manufacturers, reducing the overall tax burden, reducing the cost of loans and energy resource, developing exports, stimulating regional development, and ensuring the country's food security.

Digitization of economic processes is becoming a comprehensive trend, encompassing not only the information and communications industry, but also all areas of business activity.

Under these conditions, individual regions of the country are beginning to actively join the process of forming and implementing strategic decisions in the field of the digital economy.

It should be noted that the analyzed composition of the objectives of the development of the digital economy has a peculiarity due to the fact that the survey mainly processed data from developing countries (Brazil, Mexico, Russia, etc.).

In Russia, the term "digital economy" was received in 2017 the official state definition contained in the Strategy for the Development of the Information Society in the Russian Federation, approved by the President of the Russian Federation on May 9, 2017. The development of digital economy in the Russian Federation in accordance with the program adopted in 2017 takes into account and complements the objectives of the national technological initiative (NTI), which is one of the priorities of state policy. It serves as a definite basis for developing an understanding and long-term forecasting of the development of advanced technological solutions for ensuring national security, improving the quality of life of people, and developing new technological sectors.

In 2017-2020, the following allocations from the federal budget were planned [5] for the implementation of NTI: in $2017,2.0$ billion rubles; in 2019, 1.8 billion rubles; in 2020 1.6 billion rubles.

One of the peculiarities of the development of the digital economy is the rather high probability of monopolization/oligopolization of new markets and the concentration of the bulk of newly created or rapidly growing companies in several centers (USA, Western Europe). In this regard, it is characteristic that the main concentration of members of working groups and associations implementing NTIs falls on Moscow and the Moscow Region, as well as St. Petersburg, Kazan and a number of other cities in Russia. In this regard, today it is important to determine the priorities for the implementation of digitalization processes in the branches of the regional economy of the Republic of Bashkortostan. To this end, on July 21, 2017, the Concept of the Bashkir Technology Initiative (BTI) was approved by the governmental order of the Republic of Bashkortostan. This document identifies priority areas for the use of BTI and their relationship with NTI.

The development of the digital economy is currently one of the most significant global trends, the consequences of which are felt in various living environments. In these conditions, many countries have developed and implemented strategies and plans for the formation of the digital economy. In Russia, as well as in many regions of the country, in 2017, documents were adopted defining the prospects for this area. However, as the analysis showed, the implementation of these documents in the regions, as well as in the Republic of Bashkortostan, is currently not paying enough attention to assessing the digitization of the functioning of the regional economy and the appropriate response measures from local authorities and business [6].

Russia has all the necessary prerequisites for realizing the digital potential and accelerating the pace of digitalization. New technologies will influence the development of business and public administration, the growth of the quality of life, the emergence of new forms of socialization of people and communications.

In general, digitalization will create a synergistic effect and lead to the general growth of the economy of the regions and the country as a whole.

Now, one of the main obstacles to the development of the digital economy is the lack of coherent actions by the state, business and the scientific community.

\subsection{Regional Finance}

In a democracy, one of the important components of the state's financial system is regional finance.

In this regard, the formation and use of financial resources are of particular importance for the regional economy. 
The financial resources of the region are the finances funds at the disposal of the region, economic entities and the population, formed in the process of distribution and redistribution of the regional gross product and intended to ensure expanded reproduction in this territory.

Financial resources or the financial potential of a region depend, first of all, on the efficiency of business entities in a given territory, on the size of income and profits [9].

Lack of financial resources leads to a decrease in financial capacity and uneven development of the region.

As an example of the replenishment of financial resources, we can consider the collection of taxes. Analyzing the collection of tax collection in the regions of the country in recent years and the size of subsidies from the federal budget, it can be stated that only 3 regions of the country provide almost half of the tax collection, 72 regions are subsidized.

At the same time, we state the growth of taxes and fees. At the end of 2017, the federal budget received 9 trillion rubles, which is $32 \%$ higher than the 2016 figure. The performance of 17 regions deteriorated, while in 2015 there were 32 such [13].

Analytics show that, in fact, the growth in tax revenues was allowed by the revenues of Russia's largest taxpayers, the oil companies, due to rising oil prices. This shows that the tax system for collecting in the regions is not working enough, the mechanism for replenishing the financial resources of the regions is imperfect.

The total volume of subsidies to the regions in 2017 increased by 100 billion rubles, compared to 2016, in 2018 amounted to 645.14 billion rubles, in 2019675.60 billion rubles are planned.

Table 1 shows the ranking of the 10 most subsidized regions of Russia from 2016-2019.

Table 1. Subsidized regions

\begin{tabular}{|l|l|}
\hline 1 & Republic of Dagestan \\
\hline 2 & Republic of Sakha \\
\hline 3 & Kamchatka Territory \\
\hline 4 & Republic of Crimea \\
\hline 5 & Chechen Republic \\
\hline 6 & Altai Territory \\
\hline 7 & Republic of Tyva \\
\hline 8 & Republic of Buryatia \\
\hline 9 & Stavropol Territory \\
\hline 10 & Republic of Bashkortostan \\
\hline
\end{tabular}

As for donor regions, out of 85 regions in the Russian Federation, only 10 are donors. Table 2 lists the donor regions from 2016 to 2019.

Table 2. Donor Regions

\begin{tabular}{|l|l|}
\hline 1 & Moscow \\
\hline 2 & Moscow Region \\
\hline 3 & Leningrad Region \\
\hline 4 & Republic of Tatarstan \\
\hline 5 & Sverdlovsk Region \\
\hline 6 & Chelyabinsk Region \\
\hline 7 & Tyumen Region \\
\hline 8 & Nenets AA \\
\hline 9 & Khanty-Mansi AA \\
\hline 10 & Yamalo-Nenets AA \\
\hline
\end{tabular}

Thus, the problem of the regions continues to be their uneven economic development. Therefore, one of the most important tasks at the present stage in Russia is to equalize the differences between regions.

The state program "Regional Policy and Federal Relations" developed by the government, calculated until 2020 in order to ensure the balanced development of all the subjects (districts) of the Russian Federation, has not yet reached the goal [11].

In recent years (2017-2019), the regional economy has begun to improve. The crisis state in the country continues, the incomes of the population in most regions are declining. Among regions with growing monetary incomes of the population, highly subsidized and underdeveloped dominate. It can explain:

- the increased employment rate in the public sector;

- slow optimization of spending budgets on social security and payment of benefits;

- the increased employment rate in the informal economy.

Only a targeted financial policy of the region should be a factor in its successful economic development. Problems of the financial stability of the regions are very complex and do not fully meet the requirements of the time. This shows a weak government regulation and the lack of strategic financial management of the regions, in general - the development of the economy of regions in the Russian Federation.

The Ministry of Economy sees a way out of the current situation in carrying out structural reforms and suggests dividing the Russian Federation into 14 micro-regions, which will become centers of economic growth.

Since the beginning of the century, Russia has already experienced several stages of "regional restructuring".

In 2000 , by a presidential decree, federal districts were created in Russia, headed by plenipotentiary representatives of the head of state to better manage regions.

In 2003 - 2008, the number of subjects of the Russian Federation was reduced from 89 to 83 due to the consolidation of territories. This, also, was done to strengthen the "vertical power"; small, insignificant links were removed. At the present time, a completely different approach is taken as a basis. Macroregions are proposed to allocate, taking into account the existing socio-economic relations.

Russia at the present stage has two regions with such status - the Far East and the North Caucasus. They are invited to add another 12 on the basis of federal districts: Central, Central Black Earth, Northern, Northwestern, Southern, Volga-Kama, Volga - Ural, Ural, West Siberian, South Siberian, Yenisei, Baikal.

In each of them, at least one large center of economic growth must be created, which will pull all the others along. According to the Ministry of Economic Development, such a division will increase the level of interaction between the regions and give impetus to the development of the economy.

Many economists, experts see this as a certain potential that will lead to the optimization of economic policy, but much will depend on how it is organized. 


\section{Conclusion}

The diverse structure of the regional economy in Russia leads to the fact that the regions are not equally adapted to changing economic conditions. The development of the regions takes place with significant differences in the conditions of reproduction: the regions are to varying degrees provided with natural resources, differ greatly in climatic conditions, demographic processes, economic and scientific-technical potentials.

At present, in the conditions of the economic crisis, these differences are to a certain extent smoothed out by redistributing budget resources. This, in turn, leads to a significant flow of resources of raw materials regions into the state budget, other regions.

The regional economy is the most important component of the national economy of Russia, and its development is the task of all authorities: federal, regional and local.

Problems of development of regional economies are due to their features, the understanding of which plays an important role in the planning of the federal budget, as well as in addressing the issue of financing a particular region. This article considered the main, in the opinion of the author, features of the development of the regional economy of Russia, and also determined the scientific and practical significance of this issue.

\section{References}

1. T.G. Sadykov, R.R. Stepanova, Municipal budgets under conditions of economic crises in Russia. SHS Web of Conf. (CILDIAN-2018 - Current Issues of Linguistics and Didactics: The Interdisciplinary Approach in Humanities and Social Sci.), 50, pp. 1-3 (2018). DOI: 10.1051/ shsconf/ 20185001219 economy

2. K.N. Yusupov, Regional Economy

3. A.V. Andreev, L.M. Borisov, E.V. Pluchevskaya, Regional economy, p. 464 (2015)

4. V.A. Agafonov, Innovative development strategy of the region, Economic sci. of modern Russia, 3 (2009)

5. Regional economy and spatial development in 2 volumes, vol. 1 (Moscow: Yurayt, 2015) 464 p.

6. C.S. Carol, Russian review, 76(4), 607-622 (2017). DOI:10.1111/rus.12149

7. T. Addison, M. Nino-Zarazua, J. Pirttila, J. of international development, 30(2), 161-172 (2018). DOI: $10.1002 /$ jid.3355

8. L. Forni, M. Pisani, Macroeconomic Dynamics, 22(2), 470-500 (2018). DO1: 3651100516000286I:10.1017/S

9. V.I. Belov, Prospects for the economic development of Russian regions: problems of choice, Management Consulting, 204(2), 176-180

10. M.A. Mateo-Perez, M.A. Martinez-Roman, Y Domenech-Lopez, Revista de cercetare si interventie sociala, 50, 96-110 (2015)

11. E.R. Toro, Revista gestion de las personas $y$ technologia, 9(25), 6-19 (2016)
12. Austrian Research and Technology Report - 2013, Retrieved from: http//www/bmvit.gv.at/innovation /index.html

13. M.V. Goryunova, L.S. Kuleshova, A.I. Khakimova, Application of signal analysis for diagnostics, IEEE (Int. Conf. on Industrial Engineering, Applications and Manufacturing (ICIEAM)), pp. 1-5 (2017). DOI: 10.1109/ICIEAM.2017.8076487

14. T.G. Sadykov, Formation of expenses of the budget Financial Economics, 4, 22 (2009)

15. T.G. Sadykov, Municipal budgets in the period of financial and economic crisis (Ufa, 2018), p. 71

16. N.T. Dao, O. Edenhofer, J. of Macroeconomics, 55, 253, 273 (2018) 